\title{
The role of Toll-like receptors-4 in the pathogenesis of development of anemia of inflammation in young children
}

\author{
H. O. Lezhenko (1D*A,E,F, A. O. Pogribna ${ }^{\mathrm{B}-\mathrm{D}}$
}

Zaporizhzhia State Medical University, Ukraine

A - research concept and design; B - collection and/or assembly of data; C - data analysis and interpretation; D - writing the article;

$\mathrm{E}$ - critical revision of the article; $\mathrm{F}$ - final approval of the article

Key words: anemia,

inflammation,

Toll-like receptors-4, young children.

Pathologia 2020; 17 (1), 26-31

*E-mail: genalezh@gmail.com

Aim. To determine the pathogenetic role of Toll-like receptors-4 (TLRs-4) in the development of anemia of inflammation $(\mathrm{Al})$.

Materials and methods. The content of TLRs- 4 , ferritin and iron in blood serum of 78 children ( $1.5 \pm 0.4$ years old on the average) was studied by enzyme-linked immunosorbent assay. The main group included 46 children with acute inflammatory bacterial diseases of the respiratory system, which were divided into 2 subgroups: the first subgroup included 24 children with $\mathrm{Al}$, the second -22 children without anemia. Depending on the etiological factor, the main group was divided into subgroups: $1 \mathrm{a}-12$ patients with $\mathrm{Al}$, Streptococcus pneumoniae was detected as the pathogen, $1 \mathrm{~b}-12$ patients with $\mathrm{Al}$, the pathogen Haemophilus influenzae, $2 a-11$ patients without $\mathrm{Al}$, the pathogen - Streptococcus pneumoniae, $2 \mathrm{~b}-11$ patients without $\mathrm{Al}$, the pathogen - Haemophilus influenzae. The comparison group included 16 children with iron deficiency anemia without inflammatory manifestations. Control group included 16 conditionally healthy children. The observation groups were representative by age and sex of the children.

Results. It was determined that the content of TLRs-4 in children in the main group depended on the bacterial pathogen. The content of TLRs-4 in the subgroup where Haemophilus influenzae was the etiological factor exceeded more than 2 times the results of the control group $(\mathrm{P}<0.05), 1.7$ times the comparison group, and 2 times relative to their content in the group, where the disease was caused by Streptococcus pneumoniae $(P<0.05)$. There was a close correlation between the content of TLRs-4 in the group of patients whose disease was caused by gram-negative flora and the content of ferritin $(r=0.8, P<0.05)$. The iron in the blood serum of children with anemia of inflammation was significantly lower than in the comparison and control groups by 1.6 times $(8.78(6.8215 .30) \mathrm{ng} / \mathrm{ml}$ and $13.88(12.74-16.52) \mathrm{ng} / \mathrm{ml}$, respectively, $\mathrm{P}<0.05)$.

Conclusions. The development of $\mathrm{Al}$ in young children is accompanied by an increase in TLRs-4, primarily in response to the intrusion of gram-negative microflora (Haemophilus influenzae). The content of ferritin is directly dependent on their level, which suggests the starting role in the protective mechanism of iron sequestration, which is an important link in the pathogenesis of the development of Al.

Киючові слова: анемія запалення, Тоl-подібні рецептори-4, маленькі діти.

Патологія. 2020. T. 17, № 1(48).

C. 26-31

\section{Роль Тoll-подібних рецепторів-4 в патогенезі розвитку анемії запалення в дітей раннього віку}

\section{Г. О. Аеженко, А. О. Погрібна}

Мета роботи - вивчення патогенетичної ролі Тоll-подібних рецепторів-4 (ТПР-4) у розвитку анемії запалення.

Матеріали та методи. Вивчили вміст ТПР-4, феритину й заліза в сироватці крові 78 дітей (середній вік $-1,5 \pm 0,4$ року) методом імуноферментного аналізу. В основну групу включили 46 дітей, які мали гострі запальні бактеріальні захворювання органів дихання; групу поділили на 2 підгрупи: перша - 24 дитини з анемією запалення, друга - 22 дитини без анемії. Залежно від етіологічного чинника основну групу дослідження поділили на підгрупи: 1 a -12 пацієнтів з анемією запалення, збудник - Streptococcus pneumoniae, $1 \mathrm{~b}$ - 12 дітей з анемією запалення, збудник Haemophilus influenzae, 2a - 11 хворих без анемії запалення, збудник - Streptococcus pneumoniae, $2 \mathrm{~b}$ - 11 осіб без анемії запалення, збудник - Haemophilus influenzae. У групу порівняння залучили 16 дітей із залізодефіцитною анемією без запальних проявів, у контрольну групу - 16 умовно здорових дітей. Групи спостереження репрезентативні за віком і статтю дітей.

Результати. Встановили, що вміст ТПР-4 в дітей основної групи залежав від бактеріального збудника. Вміст ТПР-4 в підгрупі, де етіологічним фактором була Haemophilus influenzae, більш ніж удвічі перевищував результати групи контролю ( $p<0,05)$, в 1,7 раза - групи порівняння, вдвічі - щодо вмісту у групі, де захворювання зумовлено Streptococcus pneumoniae $(p<0,05)$.

Встановили тісний прямий кореляційний зв'язок між концентрацією ТПР-4 у групі пацієнтів, захворювання яких спричинене грамнегативною фолорою, та вмістом феритину $(r=0,8, p<0,05)$. Вміст заліза в сироватці крові дітей з анемією запалення був вірогідно нижчим, ніж показники груп порівняння та контролю в 1,6 раза $(8,78(6,82-15,30)$ нг/мл і 13,88 $(12,74-16,52)$ нг/мл відповідно, $p<0,05)$.

Висновки. Розвиток анемії запалення в дітей раннього віку супроводжується підвищенням рівня ТПР-4, передусім у відповідь на грамнегативну мікрофрлору (Haemophilus influenzae). Вміст феритину прямо залежить від їхнього рівня, що дає підстави для припущення щодо пускової ролі ТПР-4 в захисному механізмі секвестрації заліза, який є найважливішою ланкою в патогенезі розвитку анемії запалення. 


\section{Роль Toll-подобных рецепторов-4 в патогенезе развития анемии воспаления у детей раннего возраста}

\section{Г. А. Леженко, А. А. Погребная}

Цель работы - изучение патогенетической роли Тоll-подобных рецепторов-4 (ТПР-4) в развитии анемии воспаления.

Материалы и методы. Изучили содержание ТПР-4, ферритина и железа в сыворотке крови 78 детей (средний возраст 1,5 \pm 0,4 года) методом иммуноферментного анализа. В основную группу включили 46 детей с острыми воспалительными бактериальными заболеваниями органов дыхания, которых поделили на 2 подгруппы: первая - 24 ребенка с анемией воспаления, вторая - 22 ребенка без анемии. В зависимости от этиологического фрактора основную группу исследования разделили на подгруппы: 1a - 12 пациентов с анемией воспаления, возбудитель - Streptococcus pneumoniae, 1b - 12 больных с анемией воспаления, возбудитель - Наemophilus influenzae, $2 \mathrm{a}$ - 11 детей без анемии воспаления, возбудитель - Streptococcus pneumoniae, 2b - 11 пациентов без анемии воспаления, возбудитель - Haemophilus influenzae. Группу сравнения составили 16 детей с железодефицитной анемией без воспалительных проявлений, контрольную группу - 16 условно здоровых детей. Группы наблюдения репрезентативны по возрасту и полу детей.

Результаты. Установлено, что содержание ТПР-4 у детей в основной группе зависело от бактериального возбудителя. Содержание ТПР-4 в подгруппе, где этиологическим фрактором был Haemophilus influenzae, превышало более чем 2 раза результаты группы контроля ( $<<0,05)$, в 1,7 раза - группы сравнения, в 2 раза больше относительно их содержания в группе, где заболевание было обусловлено Streptococcus pneumoniae $(p<0,05)$. Отмечена тесная прямая корреляционная связь между содержанием ТПР-4 в группе пациентов, заболевание которых вызвано грамотрицательной флорой, и содержанием ферритина $(r=0,8, p<0,05)$. Содержание железа в сыворотке крови детей с анемией воспаления было достоверно ниже показателей групп сравнения и контроля в 1,6 раза $(8,78(6,82-15,30)$ нг/мл и 13,88 (12,74-16,52) нг/мл соответственно, $p<0,05)$.

Выводы. Развитие анемии воспаления у детей раннего возраста сопровождается повышением уровня ТПР-4, прежде всего в ответ на внедрение грамотрицательной микрофлоры (Haemophilus influenzae). Содержание ферритина находится в прямой зависимости от их уровня, что позволяет предположить пусковую роль ТПР-4в защитном механизме секвестрации железа, который является важнейшим звеном в патогенезе развития анемии воспаления.

Toll-like receptors (TLRs) are important mediators of the inflammatory response and the corresponding activation of immune cells in response to the development of the infectious process and tissue damage. They are expressed on macrophages, neutrophils, natural killers, dendritic cells and recognize highly conserved type molecules characteristic for entire groups of microorganisms, the so-called "pathogen-associated microbial patterns". Components of bacterial walls can serve as examples of such structures: lipopolysaccharides of gram-negative bacteria, peptidoglycans and lipoteichoic acids of gram-positive bacteria, flagellin, viral nucleic acids [1]. However, despite the very wide variety of receptors in this family, it was found that TLRs-4 bind predominantly to bacterial antigens [2].

It is known that in response to the inflammatory process, an increase in hematopoiesis is observed, which is due to the satisfaction of a high need for an immune response. Signaling of Toll-like receptors is involved in the regulation of hematopoiesis by inducing proliferation and differentiation of cells of myeloid origin in response to the inflammatory process in the body [3], and its violation can lead to a disorder in normal hematopoiesis [4].

Hemoglobin released during erythrocyte lysis can initiate TLRs-4-dependent signaling and trigger NF-KB activation in surrounding cells [5]. The role of TLRs-4 has been proven in the implementation of hemophagocytosis, which occurs in response to their recognition of bacterial pathogens, by inducing macrophages [6].

Given the study of anemia of inflammation (AI), of particular interest are the studies of Paula G. Fraenkel (2016), which demonstrate the activation of TLRs-4 signaling in response to the release of lipopolysaccharide due to bacterial infection, which, in turn, leads to increased production of pro-inflammatory cytokines inducing the production of the main protein of iron depot in the reticuloendothelial system - ferritin [7-9].

\section{Aim}

To determine the pathogenetic role of Toll-like receptors-4 (TLRs-4) in the development of anemia of inflammation.

\section{Materials and methods}

We observed 78 young children: the average age of the patients was $1.5 \pm 0.4$ years. The main group included 46 children with acute inflammatory bacterial diseases of the respiratory organs: acute bronchitis was diagnosed in 35 patients, pneumonia - in 11 children. Taking into account the hematological picture, the patients of the main group were divided into two subgroups: the first subgroup consisted of 24 children with $\mathrm{Al}$, which was diagnosed 4-5 days after the onset of the disease, the second -22 children with acute bacterial diseases of the respiratory tract without manifestations of anemia. The dominant pathogens of acute bacterial bronchitis were identified: Haemophilus influenzae - in 18 (50\%) children, Streptococcus pneumoniae - in 16 (44\%); pneumonia - Streptococcus pneumoniae - in 7 (58.3\%) children, Haemophilus influenzae - in 5 (41.6\%). Depending on the etiological factor, the main group of the study was divided into four subgroups: subgroup 1a consisted of 12 patients with $\mathrm{Al}$, Streptococcus pneumoniae was identified as a pathogen, subgroup $1 \mathrm{~b}$ consisted of 12 patients with $\mathrm{Al}$, the pathogen - Haemophilus influenzae, subgroup 2a included 11 patients without $\mathrm{Al}$, the pathogen - Streptococcus pneumoniae, subgroup $2 \mathrm{~b}$ included 11 patients without $\mathrm{Al}$, the pathogen - Haemophilus influenzae.
Ключевые слова: анемия воспаления, Toll-подобные рецепторы-4, Аети млаАшего возраста.

Патология. 2020 T. 17, № 1(48).

C. 26-31 
Table 1. The TLRs-4 content in the blood serum of the observation groups (Me(Q25; Q75))

\begin{tabular}{|c|c|c|c|c|}
\hline \multirow[t]{2}{*}{ Indicator } & \multicolumn{2}{|c|}{ Main group, $n=46$} & \multirow{2}{*}{$\begin{array}{l}\text { Comparison } \\
\text { group, } n=16\end{array}$} & \multirow{2}{*}{$\begin{array}{l}\text { Control group, } \\
n=16\end{array}$} \\
\hline & $\begin{array}{l}\text { Subgroup 1, } \\
n=24\end{array}$ & $\begin{array}{l}\text { Subgroup 2, } \\
n=22\end{array}$ & & \\
\hline TLRs-4, ng/ml & $\begin{array}{l}0.16(0.10 \\
0.25)^{\star}\end{array}$ & $\begin{array}{l}0.14(0.19 \\
0.20)^{*}\end{array}$ & $\begin{array}{l}0.14(0.12 ; \\
0.16)\end{array}$ & $0.1(0.09 ; 0.12)$ \\
\hline $\begin{array}{l}\text { Coefficient of } \\
\text { variation }(\mathrm{Cv}), \%\end{array}$ & 58.50 & 40.90 & 19.30 & 14.04 \\
\hline
\end{tabular}

*: $\mathrm{P}<0.05$ the significance of differences compared with the control group indicators.

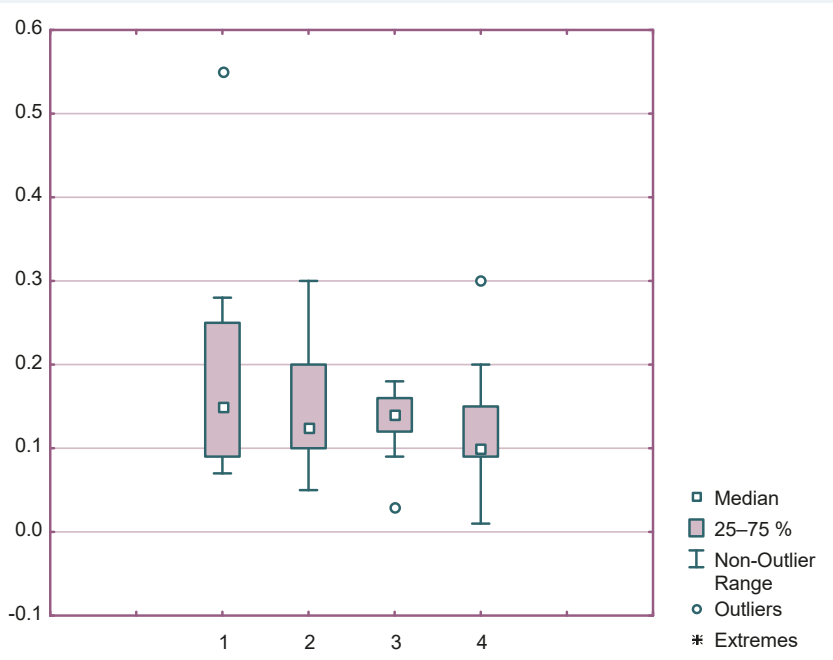

Fig. 1. Diagram of variation of TLRs-4 content in the blood serum of the observation groups.

1: the first subgroup; 2 : the second subgroup; 3: comparison group; 4: control group.

The comparison group consisted of 16 children with iron deficiency anemia without manifestations of inflammatory diseases of the respiratory system. The control group was represented by 16 conditionally healthy children. The observation groups were representative by age and sex of the children.

The study of the microbial spectrum of biomaterial from the mucous membranes of the oropharynx was carried out before antibiotic therapy was prescribed on the VITEK 2 COMPACT bacteriological analyzer (BioMérieux, France) using AES software: Global CLSI-based + Phenotypic.

An enzyme-linked immunosorbent assay (ELISA) determined the content of TLRs-4 and ferritin in the blood serum of children of the observation groups. For the study, the following kits were used: ELISA Kit for Toll-Like Receptor 4 (TLR4) (Cloud-Clone Corp., USA), Ferritin ELISA (ORGENTEC Diagnostika GmbH, Germany).

Statistical analysis of the data was performed using the statistical packages Excel and Statistica 13.0 (StatSoftInc. No. JPZ8041382130ARCN10-J). The coefficient of variation $\mathrm{C} v$ was calculated by the formula:

$$
C_{v}=\frac{\sigma}{M} \times 100 \% \text {, where }
$$

$\sigma$ - standard deviation, $\mathrm{M}$ - arithmetic mean.

With Cv over $20 \%$, it was considered that the variation series has a large variety, at $10-20 \%$ it is average, and with a coefficient of less than $10 \%$ the diversity is weak.
The normality check was carried out by the Shapiro-Wilk test. We used the method of correlation analysis with the calculation of the Spearman correlation coefficient. With an uneven distribution of characters and a non-linear character of the dependence, the median and quartiles were used (Me (Q25; Q75)). To assess the differences in indicators, the nonparametric Mann-Whitney U-test was calculated as a nonparametric analogue of the Student criterion. Differences were considered significant at $\mathrm{P}<0.05$.

All procedures performed in studies involving human participants were in accordance with the ethical standards of the institutional and national research committee and with the 1964 Helsinki declaration and its later amendments or comparable ethical standards. Informed consent was obtained from all individual participants included in the study. The full data set by children, their parents, and physician that support the findings of this study are not publicly available due to the restrictions of the ethics approval originally obtained.

\section{Results}

The results of the study of the TLRs- 4 content in the blood serum of children under observation are presented in Table 1.

Analyzing the results, we noted an increase in the content of TLRs-4 in children with Al. A significant difference between the content of TLRs-4 in the blood serum of children under observation was observed only between the main group and the control group $(P<0.05)$. A tendency to increase without a statistical difference $(P>0.05)$ was revealed between the main group and the comparison group. However, taking into account the high coefficient of variation in the main group, we determined a significant variation in the results in the main group of the study (Fig. 1).

As shown in Fig. 1 in children of the first and second subgroups a wide variability in the content of TLRs-4 (0.10-0.25 ng/ml and 0.10-0.20 ng/ml, respectively) in the blood serum was demonstrated. Despite the fact that there was no significant difference between the content of TLRs-4 in the blood serum of patients of the main group and the comparison group, in contrast to the main group, the scatter of results in children with iron deficiency anemia was not significant. The smallest variability in the results of the content of TLRs-4 was observed in the control group.

Taking into account the significant variability in the content of TLRs-4 in the blood serum of patients of the main group, which indicated its heterogeneity, we ranked the results depending on the etiological factor. The data obtained confirmed the logic of the assumption made. A statistically significant increase in the level of TLRs-4 in the blood serum of patients whose diseases are caused by gram-negative flora (Haemophilus influenzae) was established (Table 2).

The data obtained indicate that the development of Al that manifested against the background of a disease caused by Haemophilus influenzae was accompanied by a statistically significant increase in the level of TLRs-4 in the blood serum more than 2 times in comparison with 
Table 2. The TLRs-4 content in the blood serum of the observation depending on the etiologic pathogen (Me(Q25; Q75))

\begin{tabular}{|c|c|c|c|c|}
\hline Indicator & Main group, $n=46$ & & Comparison group, $\mathrm{n}=16$ & Control group, $n=16$ \\
\hline \multirow[t]{2}{*}{ Streptococcus pneumoniae } & Subgroup $1 \mathrm{a}, \mathrm{n}=12$ & Subgroup $2 \mathrm{a}, \mathrm{n}=11$ & \multirow[t]{4}{*}{$0.14(0.12 ; 0.16)$} & \multirow[t]{4}{*}{$0.10(0.09 ; 0.12)$} \\
\hline & $0.10(0.07 ; 0.10)^{\#}$ & $0.10(0.10 ; 0.10)^{\#}$ & & \\
\hline \multirow[t]{2}{*}{ Haemophilus influenzae } & Subgroup $1 b, n=12$ & Subgroup $2 b, n=11$ & & \\
\hline & $0.24(0.23 ; 0.25)^{*, \#, 1}$ & $0.2(0.18 ; 0.20)^{\star, \#, 2}$ & & \\
\hline
\end{tabular}

*: $P<0.05$ the significance of differences compared with the control group indicators; \#: $P<0.05$ the significance of differences compared with the comparison group indicators; ${ }^{1}: \mathrm{P}<0.05$ the significance of differences compared with the subgroup $1 \mathrm{a} ;{ }^{2}: \mathrm{P}<0.05$ the significance of differences compared with the subgroup $1 \mathrm{~b}$.

Table 3. Some indicators of iron metabolism in the observation groups (Me (Q25; Q75))

\begin{tabular}{|c|c|c|c|c|}
\hline \multirow{2}{*}{ Indicator } & \multicolumn{2}{|l|}{ Main group, $n=48$} & \multirow[t]{2}{*}{ Comparison group, $\mathrm{n}=15$} & \multirow{2}{*}{ Control group, $n=15$} \\
\hline & Subgroup $1, n=26$ & Subgroup 2, n = 22 & & \\
\hline Hemoglobin, g/L & $100(97 ; 107)^{*}$ & $129(119 ; 136.5)^{*}$ & $101(95 ; 106)$ & $125(119 ; 132)$ \\
\hline $\mathrm{RBC}, \mathrm{T} / \mathrm{L}$ & $3.7(3.40 ; 4.01)^{*}$ & $4.49(3.94 ; 5.04)^{*}$ & $4.0(3.50 ; 4.40)$ & $4.7(4.31 ; 5.10)$ \\
\hline Ferritin, ng/mL & $56.5(48 ; 63)^{*, \#}$ & $52(45 ; 78)^{\star, \#}$ & $43.5(23 ; 48)^{*}$ & $29(16 ; 50)$ \\
\hline Iron, mol/L & $8.78(6.82 ; 15.30)^{*, \#}$ & $9.85(7.55 ; 12.50)^{*, \#}$ & $13.1(9.74 ; 17.22)$ & $13,88(12.74 ; 16.52)$ \\
\hline
\end{tabular}

*: $\mathrm{P}<0.05$ the significance of differences compared with the control group indicators; \#: $\mathrm{P}<0.05$ the significance of differences compared with the comparison group indicators.

the control groups $(P<0.05)$, and 1.7 times relative to the comparison group $(P<0.05)$. The content of TLRs-4 in the group of children with acute bacterial inflammatory diseases without Al caused by Haemophilus influenzae was 2 times higher than in the control group $(P<0.05)$ and 1.5 times higher than the results in the comparison group $(P<0.05)$. In the group of children where Haemophilus influenzae was the etiological bacterial pathogen, the level of TLRs- 4 was 2.4 times higher in the $1 \mathrm{~b}$ subgroup and 2 times in the $2 b$ subgroup compared with the indicators of the subgroups $1 \mathrm{a}$ and $2 \mathrm{a}$, in which the infection was caused by Streptococcus pneumoniae. The content of Toll-like receptors-4 in the blood serum of the main group, the main disease in which was caused by Streptococcus pneumoniae, did not differ from that in the control group, and was 1.4 times lower than in the comparison group (Table 2, Fig. 2).

Diagram of variation of the content of TLRs-4 in the blood serum showed no scatter in subgroup 2a. The smallest range of results was noted in both subgroups of the main group, where Haemophilus influenzae was the etiological factor.

We observed a direct correlation between the content of TLRs-4 in the group of patients whose disease was caused by gram-negative bacterial flora and the serum ferritin content in the children under observation $(r=0.8$, $P<0.05)$. It was noted that the content of ferritin slightly varied between subgroups of the main group, exceeding that in the control group $(P<0.05)$ and comparison $(P<0.05)$ (Table 3). The serum ferritin content in children with iron deficiency anemia exceeded that in the control group by 1.5 times $(P>0.05)$.

Hemoglobin content in the blood serum of the first subgroup of the main study group showed a characteristic laboratory picture for anemia, and corresponded to the parameters of the comparison group $(P<0.05)$.

The iron content in the blood serum of children of the main study group was significantly lower when compared with the indicators of the comparison and control group $(\mathrm{P}<0.05)$, however, its value did not differ between the subgroups of the main study group, demonstrating the developing latent iron deficiency in the second subgroup of the main group. The level of iron in the blood

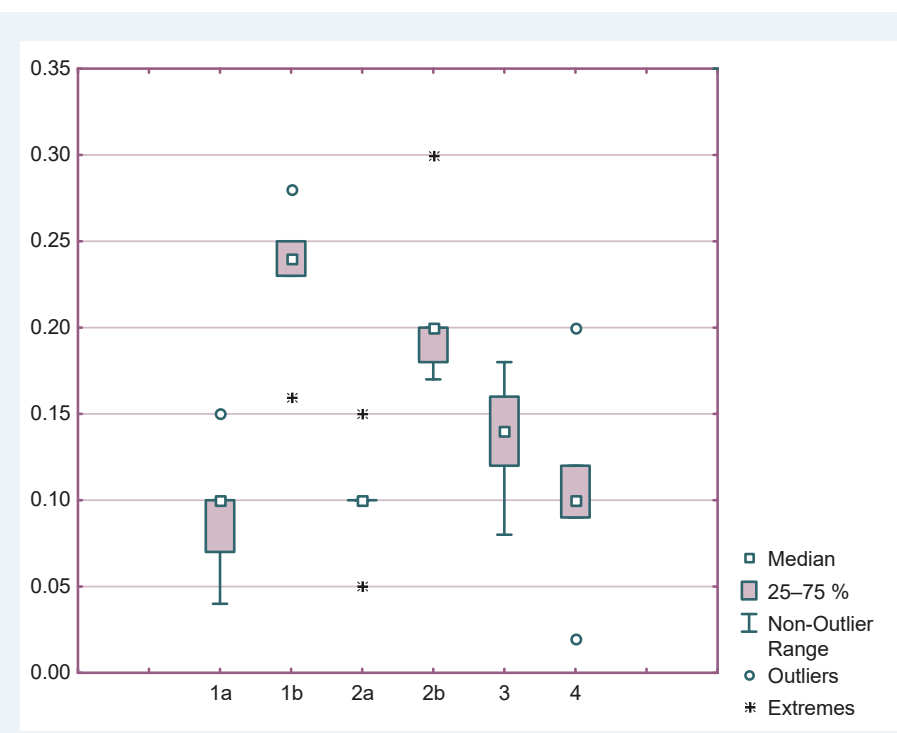

Fig. 2. Diagram of variation of TLRs-4 content in the blood serum of the observation groups depending on the etiologic pathogen.

1a: the first subgroup, the pathogen - Streptococcus pneumoniae; $1 \mathrm{~b}$ : the second subgroup the pathogen - Haemophilus influenzae; 2a: the first subgroup, the pathogen - Streptococcus pneumoniae; $2 \mathrm{~b}$ : the second subgroup, the pathogen - Haemophilus influenzae; 3: comparison group; 4: control group.

serum did not differ between the comparison and control groups $(P>0.05)$, which is explained by the planned administration of iron-containing drugs in children undergoing inpatient treatment for iron deficiency anemia. Our study demonstrates a pronounced negative correlation between the content of ferritin and the level of iron in the blood serum of children who were under observation $(r=-0.8, P<0.05)$, which looks logical, taking into account the pathogenesis of Al, the main link which is represented by sequestration of iron in the depot.

\section{Discussion}

Summarizing the data obtained, it can be said that the development of $\mathrm{Al}$ in young children with bacterial diseases of the respiratory system proceeds against 
the background of a high level of TLRs-4. Additionally, it was found that the content of TLRs-4 varied significantly and was statistically significantly increased in cases where Haemophilus influenzae was the etiological factor of the disease. The obtained data can be explained by the structural features of bacterial pathogens. The walls of gram-negative bacteria contain lipopolysaccharide endotoxin, which is responsible for the activation of innate defense mechanisms through TLRs-4. In turn, lipoteichoic acid, peptidoglycan, and lipoproteins are located on the walls of gram-positive bacteria, which induce inflammatory reactions mainly through TLRs-2 [9].

The results of our study also demonstrate the difference between high levels of ferritin and the iron content in the blood serum of children with iron deficiency anemia compared with a group of relatively healthy children. We suggest that the administration of iron-containing medicines to inpatient children was a compensating factor for iron deficiency in the blood. The studies of $F$. Dumler $(2003)[5,10]$ support our assumption. In turn, the revealed direct correlation between TLRs-4 and ferritin against the background of a reliably low iron level in children of the first subgroup and latent iron deficiency in children of the second subgroup probably indicates immuno-sequestered iron sequestration in children from the first subgroup, which is a leading pathogenetic link in the development of Al. Taking into account the literature data, we can assume that iron sequestration is the result of activation of a number of its redistribution mechanisms by proinflammatory cytokines in case of $\mathrm{Al}$, in particular, induction of ferritin expression $[6,10,12]$. The high content of Toll-like receptors- 4 in serum with inflammation anemia, proportional to the level of ferritin, suggests their protective role, aimed at inhibiting the transport of iron in the body. Our assumption is consistent with studies by Carole Peyssonnaux et al. (2006), in which the direct role of TLRs-4 in the inhibition of ferroportin is indicated, which leads to disruption of the transport of cellular iron into blood plasma $[3,8,14]$. These data indicate a coordinated innate immune response of macrophages in response to TLRs- 4 signals to a decrease in iron export by ferroportin at both transcriptional and post-translational levels $[3,15]$.

\section{Conclusions}

1. The development of $A l$ in young children is accompanied by an increase in the level of TLRs-4, primarily in response to the intrusion of gram-negative microflora (Haemophilus influenzae).

2. The content of the protein complex of ferritin iron deposition is directly dependent on the level of TLRs-4, which suggests the role of the latter in the protective mechanism of iron sequestration, which is an important link in the pathogenesis of the development of inflammation anemia.

\section{Funding}

The research was funded by Zaporizhzhia State Medical University.
Conflict of interest: authors have no conflict of interest to declare. Конфмікт інтересів: віАсутній.

Надійшла Ао редакції / Received: 02.02.2020

Після Аоопрацювання / Revised: 17.02.2020

Прийнято Ао Аруку / Accepted: 26.02.2020

Information about authors:

Lezhenko H. O., MD, PhD, DSc, Head of the Department of Hospital Pediatrics, Zaporizhzhia State Medical University, Ukraine.

ORCID ID: 0000-0003-0851-4586

Pogribna A. O., PhD Student of the Department of Hospital Pediatrics, Zaporizhzhia State Medical University, Ukraine.

\section{Відомості про авторів:}

^еженко Г. О., А-р меА. наук, професор, зав. каф. госпітальної педіатрії, Запорізький державний меАичний університет, україна.

Погрібна А. О., PhD аспірант каф. госпітальної педіатрії,

Запорізький державний медичний університет, Україна.

\section{Сведения об авторах:}

Леженко Г. А., А-р меА. наук, профессор, зав. каф. госпитальной педиатрии, Запорожский государственный меАицинский университет, Украина.

Погребная А. А., PhD аспирант каф. госпитальной педиатрии, Запорожский государственный медицинский университет, Украина.

\section{References}

[1] Herbst-Kralovetz, M. M., Quayle, A. J., Ficarra, M., Greene, S., Rose W. A., Chesson, R., Spagnuolo, R. A., \& Pyles, R. B. (2008). Quantification and comparison of toll-like receptor expression and responsiveness in primary and immortalized human female lower genital tract epithelia. American Journal of Reproductive Immunology, 59(3), 212-224. https:// doi.org/10.1111/j.1600-0897.2007.00566.x

[2] Jin, R. R., Liu, L., Zhu, W. C., Li, D. Y., Yang, L., Duan, J. M., Cai, Z. Y., Nie, Y., Zhang, Y. J., Gong, Q. Y., Song, B., Wen, L. P., Anderson, J. M., \& Ai, H. (2019). Iron oxide nanoparticles promote macrophage autophagy and inflammatory response through activation of toll-like $\mathrm{Re}$ ceptor-4 signaling. Biomaterials, 203, 23-30. https://doi.org/10.1016/j. biomaterials.2019.02.026

[3] Peyssonnaux, C., Zinkernagel, A. S., Datta, V., Lauth, X., Johnson, R. S., \& Nizet, V. (2006). TLR4-dependent hepcidin expression by myeloid cells in response to bacterial pathogens. Blood, 107(9), 37273732. https://doi.org/10.1182/blood-2005-06-2259

[4] Fraenkel, P. G. (2017). Anemia of Inflammation A Review. Medical Clinics of North America, 101(2), 285-+. https://doi.org/10.1016/j. mcna.2016.09.005

[5] Dumler, F. (2003). Long term iron therapy increases serum ferrtin values in hemo (HD) and peritoneal dialysis (PD) patients. ASAIO, 49(2), 188. https://doi.org/10.1097/00002480-200303000-00190.

[6] Weiss, G., Ganz, T., \& Goodnough, L. T. (2019). Anemia of inflammation. Blood, 133(1), 40-50. https://doi.org/10.1182/blood-201806-856500

[7] Gnana-Prakasam, J. P., Martin, P. M., Mysona, B. A., Roon, P., Smith, S. B., \& Ganapathy, V. (2008). Hepcidin expression in mouse retina and its regulation via lipopolysaccharide/Toll-like receptor-4 pathway independent of Hfe. Biochemical Journal, 411, 79-88. https://doi. org/10.1042/bj20071377

[8] Ramey, G., Deschemin, J. C., Durel, B., Canonne-Hergaux, F., Nicolas, G., \& Vaulont, S. (2010). Hepcidin targets ferroportin for degradation in hepatocytes. Haematologica-the Hematology Journal, 95(3), 501-504. https://doi.org/10.3324/haematol.2009.014399

[9] Branger, J., Knapp, S., Weijer, S., Leemans, J. C., Pater, J. M., Speelman, P., Florquin, S. R., \& van der Poll, T. (2004). Role of tolllike receptor 4 in gram-positive and gram-negative pneumonia in mice. Infection and Immunity, 72(2), 788-794. https://doi.org/10.1128/ iai.72.2.788-794.2004

[10] Nemeth, E., Tuttle, M. S., Powelson, J., Vaughn, M. B., Donovan, A., Ward, D. M., Ganz, T., \& Kaplan, J. (2004). Hepcidin regulates cellular iron efflux by binding to ferroportin and inducing its internalization. Science, 306(5704), 2090-2093. https://doi.org/10.1126/ science.1104742 
[11] Roy, C. N., Custodio, A. O., de Graaf, J., Schneider, S., Akpan, I., Montross, L. K., Sanchez, M., Gaudino, A., Hentze, M. W., Andrews, N. C., \& Muckenthaler, M. U. (2004). An Hfe-dependent pathway mediates hyposideremia in response to lipopolysaccharide-induced inflammation in mice. Nature Genetics, 36(5), 481-485. https://doi. org/10.1038/ng1350

[12] Maratheftis, C. I., Andreakos, E., Moutsopoulos, H. M., \& Voulgarelis, M. (2007). Toll-like receptor-4 is up-regulated in hematopoietic progenitor cells and contributes to increased apoptosis in myelodysplastic syndromes. Clinical Cancer Research, 13(4), 1154-1160. https://doi. org/10.1158/1078-0432.ccr-06-2108

[13] Sharma, J., Boyd, T., Alvarado, C., Gunn, E., Adams, J., Ness, T., Dunwoody, R., Lamb, J., House, B., Knapp, J., \& Garner, R. (2019). Reporter Cell Assessment of TLR4-Induced NF-kappa B Responses to Cell-Free Hemoglobin and the Influence of Biliverdin. Biomedicines, 7(2), Article 41. https://doi.org/10.3390/biomedicines7020041

[14] Huggins, T., Haught, J. C., Xie, S., Tansky, C. S., Klukowska, M., Miner, M. C., \& White, D. J. (2016). Quantitation of endotoxin and lipoteichoic acid virulence using toll receptor reporter gene. American Journal of Dentistry, 29(6), 321-327.

[15] Kim, A., Fung, E., Parikh, S. G., Valore, E. V., Gabayan, V., Nemeth, E., \& Ganz, T. (2014). A mouse model of anemia of inflammation: complex pathogenesis with partial dependence on hepcidin. Blood, 123(8), 11291136. https://doi.org/10.1182/blood-2013-08-521419. 